\title{
Penerapan Metode EKSPERIMEN Terhadap AKTIVITAS Dan HASIL Belajar PAda MATeri Elastisitas Bahan
}

\author{
Nurussaniah $^{1)}$, Dwi Fajar Saputri ${ }^{2)}$, dan Ade Mariadi ${ }^{3)}$ \\ 1) Prodi Pendidikan Fisika IKIP PGRI Pontianak, Pontianak, Indonesia \\ E-mail:nurussaniah@gmail.com \\ 2) Prodi Pendidikan Fisika IKIP PGRI Pontianak, Pontianak, Indonesia \\ E-mail: dwifajar24@gmail.com \\ 3) MAN MODEL Singkawang, Singkawang, Indonesia \\ E-mail: ademariadi@gmail.com
}

\begin{abstract}
Abstrak. Penelitian ini bertujuan untuk mengetahui hasil belajar dan aktivitas siswa setelah diajarkan menggunakan metode eksperimen pada materi elastisitas. Metode yang digunakan dalam penelitian ini adalah penelitian eksperimen. Rancangan penelitian yang digunakan adalah The One Shot Case Study. Populasi dalam penelitian ini adalah seluruh siswa kelas XI IPA MAN Model Singkawang 2014/2015 yang terdiri dari tiga kelas. Sampel yang dipilih terdiri dari satu kelas (kelas eksperimen) yang diambil menggunakan teknik cluster random sampling. Teknik pengumpul data yang digunakan yaitu pengukuran dan observasi langsung. Data hasil belajar siswa diperoleh dari tes hasil belajar berupa tes esai, sedangkan data aktivitas siswa diperoleh melalui lembar observasi. Teknik analisis data yang digunakan untuk mengetahui ketercapaian hasil belajar siswa terhadap KKM menggunakan statistik inferensial. Sedangkan untuk mengetahui aktivitas siswa menggunakan rumus persentase. Dari hasil analisis data diperoleh bahwa thitung $>$ ttabel yaitu 4,256 > 1,703 hal ini menunjukkan bahwa hasil belajar siswa yang diajarkan dengan metode eksperimen mencapai KKM pada materi elastisitas bahan. Hasil belajar siswa yang diajarkan menggunakan metode eksperimen mempreroleh nilai rata-rata sebesar78 dan aktivitas siswa tergolong baik dengan persentase nilai rata-rata 70,89\%.
\end{abstract}

Kata Kunci: eksperimen, hasil belajar, aktivitas

\section{Pendahuluan}

Pelajaran Fisika merupakan salah satu bagian dari Ilmu Pengetahuan Alam (IPA) yang penting dipelajari oleh siswa. Hal ini tercantum dalam salah satu tujuan mata pelajaran fisika untuk tingkat SMA, yaitu mengembangkan pengalaman untuk dapat merumuskan masalah, mengajukan dan menguji hipotesis melalui percobaan, merancang dan merakit instrumen percobaan, mengumpulkan, mengolah, dan menafsirkan data, serta mengkomunikasikan hasil percobaan secara lisan dan terulis [1]. Berdasarkan hal tersebut, jelas bahwa pelajaran fisika merupakan sarana bagi siswa untuk memupuk sikap ilmiah, menguasai konsep dan prinsip fisika, dapat merumuskan masalah serta menyelesaikan masalah secara ilmiah. Melalui hal ini, dengan belajar fisika dapat mengembangkan kemampuan siswa dalam menyelesaikan masalah.
Kegiatan pembelajaran yang melibatkan siswa untuk khusunya dalam pembelajaran Fisika akan berdampak baik pada hasil belajarnya. Belajar sambil melakukan aktivitas lebih banyak mendatangkan hasil bagi anak didik, sebab kesan yang didapatkan oleh anak didik lebih tahan lama tersimpan didalam benak anak didik. Keberhasilan siswa dalam belajar tergantung pada aktivitas yang dilakukannya selama proses pembelajaran [2]. Oleh karena pentingnya aktivitas siswa dalam proses pembelajaran maka pendidik dituntut untuk mengetahui dan memahami aktivitas belajar siswa. Pendidik memegang peranan penting untuk mendorong aktivitas siswa sehingga siswa termotivasi untuk meningkatkan hasil belajarnya.

Sebagian besar siswa mengahadapi masalah di dalam mata pelajaran Fisika salah satunya materi elastisitas bahan. Berdasarkan hasil observasi kesulitan siswa tersebut ditandai jika guru memberikan pertanyaan sesuai dengan topik yang 


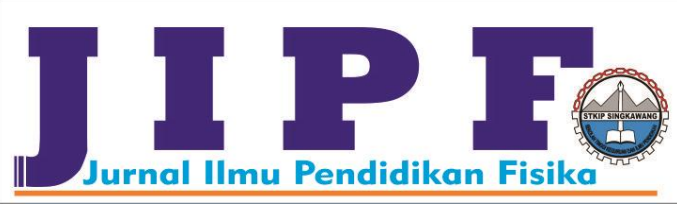

telah diberikan, siswa tidak dapat menjawabnya, sebaliknya apabila guru meminta siswa menanyakan hal yang mereka tidak mengerti tentang topik tersebut mereka juga enggan untuk bertanya. Oleh sebab itu, proses belajar mengajar di dalam kelas tidak berlangsung efektif dan terlihat satu arah, dengan kondisi guru memberikan penjelasan dan siswa hanya mendengarkan. Siswa lebih memilih untuk menjadi pendengar yang baik dan tidak berusaha aktif. Sikap diam siswa tidak berarti bahwa mereka sudah memahami materi yang telah disampaikan oleh guru.

Berdasarkan permasalahan tersebut, perlu dicari solusi untuk mengatasi kesulitan siswa dalam mempelajari materi elastisitas bahan. Guru perlu merancang suatu pembelajaran yang menarik, menyenangkan, agar siswa belajar lebih rileks dan aktif, sehingga dapat menarik minat siswa dalam belajar fisika terutama pada materi elastisitas bahan. Peran guru sangat penting untuk membimbing, mengarahkan dan mengajarkan siswa agar siswa dapat mengembangkan kemampuan dan mengasah kemampuan berpiirnya. Cara guru dalam menyampaikan materi bila dikemas dengan kreatif dan inovatif akan memperngaruhi situasi, motivasi belajar serta hasil belajar siswa. Hasil belajar adalah suatu kemampuan yang dimiliki siswa setelah dia menerima pengalaman belajarnya yang baru [3]. Salah satu caranya adalah dengan menggunakan metode eksperimen. Penerapan metode eksperimen dapat meningkatkan penguasaan konsep siswa.

Metode eksperimen adalah "metode yang sesuai untuk pembelajaran sains, karena metode eksperimen mampu memberikan kondisi belajar yang dapat mengembangkan kemampuan berfikir dan kreativitas secara optimal [2]. Siswa diberi kesempatan untuk menyusun sendiri konsepkonsep dalam struktur kognitifnya, selanjutnya dapat diaplikasikan dalam kehidupannya". Pada kegiatan belajar mengajar siswa diarahkan pada pemahaman konsep materi fisika sehingga dimungkinkan keaktifan berpikir siswa dalam pembelajaran fisika. Hal ini tentunya akan mempengaruhi hasil belajar fisika.

Berdasarkan uraian di atas, maka penelitian ini bertujuan untuk mengetahui ketercapaian hasil belajar siswa terhadap KKM dan aktivitas siswa setelah diterapkan metode eksperimen. Hasil penelitian ini diharapkan dapat meningkatkan hasil belajar dan aktivitas siswa pada materi elastisitas bahan. Selain itu penelitian ini juga diharapkan dapat dijadikan sebagai salah satu kajian dalam perbaikan proses pembelajaran agar mutu pendidikan dapat lebih meningkat.

\section{METODE}

Metode yang digunakan dalam penelitian ini adalah metode eksperimen. Bentuk penelitian yang digunakan dalam penelitian ini Pra Experimental. Berdasarkan bentuk penelitian, maka digunakan rancangan The One Shot Case Study seperti yang ditunjukkan pada Tabel 1. Dalam penelitian ini hanya digunakan satu kelompok sampel, di mana siswa dikenakan perlakuan tertentu, setelah itu dilakukan pengukuran terhadap siswa tersebut dengan memberikan tes akhir (post-test).

TABLE I

RANCANGAN PENELITIAN

\begin{tabular}{cccc}
\hline Kelompok & Pre-test & Perlakuan & Post-test \\
\hline Eksperimen & - & $X$ & $T_{1}$ \\
\hline
\end{tabular}

Pada Tabel 1, X merupakan pembelajaran dengan metode eksperimen merupakan post-test (tes akhir).

Populasi dalam penelitian ini adalah siswa kelas XI IPA semester genap MAN Model Singkawang Kota Singkawang tahun ajaran 2014/2015 yang terdiri dari tiga kelas. Sampel dalam penelitian ini diambil dari populasi menggunakan teknik sampling yaitu cluster random sampling yang terdiri dari satu kelas eksperimen.

Teknik pengumpulan data yang digunakan dalam penelitian ini adalah teknik pengukuran dan observasi langsung. Teknik pengukuran dilakukan untuk mengetahui data hasil belajar siswa pada materi elastisitas bahan. Kegiatan pengukuran yang dimaksud adalah pemberian tes akhir (posttest) berbentuk essay. Teknik observasi langsung dalam penelitian ini adalah untuk mengetahui aktivitas siswa dalam penerapan metode eksperimen. Alat pengumpul data dalam penelitian 


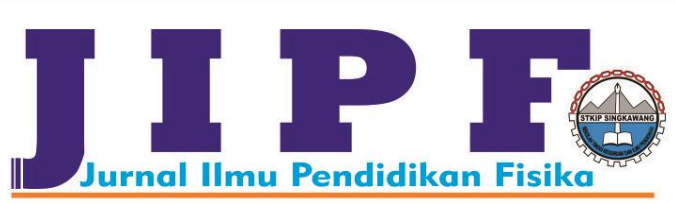

ini adalah tes dan lembar obeservasi. Tes digunakan untuk mengukur hasil belajar siswa. Jenis tes yang digunakan adalah tes hasil belajar berbentuk soal essay yang berjumlah 5 butir. Sedangkan untuk mengetahui aktivitas siswa digunakan lembar observasi.

Hasil belajar siswa setelah diterapkan pembelajaran dengan metode eksperimen dilihat ketercapaiannya berdasarkan Kriteria Ketuntasan Minimum (KKM) dengan nilai KKM 70 menggunakan statistik inferensial. Adapun langkah-langkahnya adalah sebagai berikut:

a. Menguji normalitas populasi dengan menggunakan rumus liliefors, adapun rumus liliefors menggunakan Persamaan 1.

$$
L_{\text {hitung }}=\left|F\left(Z_{i}\right)-S\left(Z_{i}\right)\right|
$$

Jika $\mathrm{L}_{\text {hitung }}<\mathrm{L}_{\text {tabel }}$ maka sampel berasal dari populasi berdistribusi normal.

b. Jika populasi berdistribusi normal, maka dilanjutkan dengan uji-t satu sampel untuk menguji hipotesis. Rumus uji-t yang digunakan Persamaan 2.

$$
t=\frac{\bar{X}-\mu_{0}}{\frac{S}{\sqrt{n}}}
$$

Pada persamaan 2, $\mathrm{t}$ merupakan nilai $\mathrm{t}$ yang dihitung $; \bar{X}$ merupakan nilai rata-rata; $\mu_{0}$ merupakan nilai yang dihopotesiskan; $S$ merupakan simpangan baku sampel, $n$ merupakan jumlah anggota sampel. $\mathrm{H}_{0}$ : Hasil belajar siswa tidak mencapai KKM (70) setelah diajarkan dengan metode eksperimen $\mathrm{H}_{\mathrm{a}}$ : Hasil belajar siswa mencapai KKM setelah diajarkan dengan metode eksperimen Jika $t_{\text {hitung }}>\mathrm{t}_{\text {tabel, }}, \mathrm{H}_{0}$ ditolak maka $\mathrm{H}_{\mathrm{a}}$ diterima

c. Jika populasi tidak berdistribusi normal, maka digunakan statistik nonparametrik. Uji yang digunakan adalah uji binomial dengan Persamaan 3.

$$
\mathrm{p}(\mathrm{x})=\left(\begin{array}{l}
\mathrm{N} \\
\mathrm{x}
\end{array}\right) \mathrm{P}^{\mathrm{x}} \mathrm{Q}^{\mathrm{N}-\mathrm{x}}
$$

Jika $\mathrm{P}(\mathrm{x}) \leq \alpha, \mathrm{H}_{0}$ ditolak, maka $\mathrm{H}_{\mathrm{a}}$ diterima

Untuk mengetahui aktivitas belajar siswa digunakan rumus persentase pada Persamaan 4.

$$
X \%=\frac{n}{N} \times 100 \%
$$

Jurnal Ilmu Pendidikan Fisika

Volum 1 Nomor 2 September 2016. Halaman 37-41 p-ISSN: 2477-5959 e-ISSN: 2477-8451

Setelah mendapatkan persentase aktivitas, selanjutnya dikategorikan berdasarkan kriteria aktivitas siswa pada Tabel 2.

TABLE 2

KRITERIA AKTIVITAS SISWA

\begin{tabular}{cc}
\hline Persentase Aktivitas Siswa & Kriteria \\
\hline $0-33,33 \%$ & Kurang \\
$33,34 \%-66,66 \%$ & Cukup \\
$66,67 \%-100 \%$ & Baik \\
\hline
\end{tabular}

\section{HASIL DAN PEMBAHASAN}

Berdasarkan hasil penelitian diperoleh data post-test (berupa skor mulai dari 0 sampai 50) yang diubah menjadi nilai (mulai dari 0 sampai 100) dari kelas eksperimen (berjumlah 27 siswa). Post-test diberikan setelah pembelajaran dengan metode eksperimen pada sampel. Rekapitulasi nilai dari hasi post-test kelas XI IPA MAN Model Singkawang pada materi elastisitas bahan dapat dilihat pada Tabel 3 .

TABLE 3

REKAPITULASI NILAI POST-TEST

\begin{tabular}{cc}
\hline Keterangan & Post-test \\
\hline Rara-Rata Nilai & 78 \\
Nilai Terendah & 60 \\
Nilai Tertinggi & 92 \\
Standar Deviasi & 9,76 \\
\% Ketuntasan & 77,78 \\
\hline
\end{tabular}

Berdasarkan Tabel 3 dapat dilihat bahwa ketuntasan klasikal mencapai $\geqslant 75 \%$ yaitu 77 , $78 \%$. Skor tertinggi 30 dan skor terendah 41 dengan nilai rata-rata 78 nilai tertinggi adalah 92 nilai terendah adalah 60 dan standar deviasi 9,76.

Hal ini sejalan dengan hasil perhitungan uji inferensial dengan uji-t satu sampel. Data hasil uji

\begin{tabular}{|c|c|c|c|}
\hline thitung $_{\text {hit }}$ & $\begin{array}{c}\text { tabel }(\alpha= \\
5 \%)\end{array}$ & $\begin{array}{c}\text { Kriteria } \\
\text { Pengujian }\end{array}$ & Keterangan \\
\hline 14,897 & 1,703 & $\begin{array}{c}\text { Jika thitung }> \\
\mathrm{t}_{\text {tabel }} \text { maka } \mathrm{H}_{0} \\
\text { ditolak }\left(\mathrm{H}_{\alpha}\right. \\
\text { diterima })\end{array}$ & $\begin{array}{c}t_{\text {hitung }}>t_{\text {tabel }} \\
(14,897>1,703) \\
\mathrm{H}_{0} \text { ditolak }\end{array}$ \\
\hline
\end{tabular}
hipotesis post-test dapat dilihat pada Tabel 4.

TABLE 3

HASIL UJI-HIPOTESIS POST-TEST SISWA

Berdasarkan Tabel 4 diketahui bahwa nilai thitung > ttabel $(14,897>1,703)$ berarti bahwa H0 ditolak dan Ha diterima. Artinya Hasil belajar 


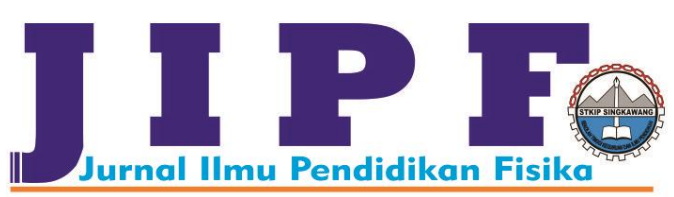

siswa setelah diajarkan dengan metode eksperimen mencapai KKM.

Hasil penelitian ini menunjukan bahwa penerapan metode eksperimen mendatangkan hasil belajar yang baik pada materi elastisitas bahan. Belajar sambil melakukan aktivitas lebih banyak mendatangkan hasil bagi anak didik, sebab kesan yang didapatkan oleh anak didik lebih tahan lama tersimpan didalam benak anak didik. Siswa pada kelas eksperimen yang diberikan perlakuan atau pembelajaran metode eksperimen dapat melihat karakteristik materi elastisitas bahan dengan jelas [2]. Siswa tidak hanya membayangkan secara abstrak, akan tetapi dapat melihat dan melaksanakan langsung konsep-konsep dalam materi elastisitas bahan yang ingin disampaikan oleh guru secara langsung. Selain itu, metode eksperimen memiliki pengaruh yang signifikan terhadap hasil belajar [4].

Metode eksperimen membuat peserta didik terlatih menggunakan metode ilmiah dalam menghadapi segala masalah sama, lebih aktif berpikir dan berbuat,memperoleh ilmu pengetahuan juga menemukan penggalan praktis serta keterampilan dalam menggunakan alat percobaan. Metode eksperimen ini mendorong siswa untuk berpikir lebih luas sehingga mereka dapat membangun pengetahuan mereka sendiri, siswa bisa mengambil kesimpulan dan dapat meningkatkan hasil belajar dan penguasaan konsep siswa karena siswa lebih mudah memahami materi dan melihat langsung proses terjadinya melalui suatu percobaan. Metode eksperimen menekankan suatu cara belajar mengajar yang melibatkan peserta didik dengan mengalami dan membuktikan sendiri proses dari hail percobaan [5].

Pembelajaran dengan metode eksperimen melatih dan mengajar siswa untuk belajar secara aktif dengan mengikuti tahap-tahap pembelajarannya. Belajar sambil melakukan aktivitas lebih banyak mendatangkan hasil bagi anak didik, sebab kesan yang didapatkan oleh anak didik lebih tahan lama tersimpan didalam benak anak didik [2]. Penerapan metode eksperimen ini diharapkan dapat membantu Siswa untuk dapat memahami konsep pada elastisitas bahan.

Aktivitas siswa dalam penelitian ini dibatasi pada indikator yang mengacu pada Paul B. Dierich () yaitu: 1) Kegiatan-kegiatan visual. 2) Kegiatankegiatan lisan. 3) Kegiatan-kegiatan mendengarkan. 4) Kegiatan-kegiatan menulis. 5) Kegiatan motorik [5]. Aktivitas siswa pada saat pembelajaran menggunakan metode eksperimen disajikan pada Tabel 5. Berdasarkan tabel tersebut, didapat nilai persentase aktivitas seluruh siswa sebesar $69,68 \%$ dengan kategori baik pada pertemuan pertama sedangkan pertemuan kedua $72,11 \%$ dengan kategori baik. Aktivitas siswa pada pertemuan kedua lebih tinggi dibandingkan pertemuan pertama.

TABLE 3

DATA AKTIVITAS SISWA

\begin{tabular}{ccc}
\hline Deskripsi Data & \multicolumn{2}{c}{ Nilai } \\
\cline { 2 - 3 } & Pertemuan 1 & Pertemuan 2 \\
\hline Jumlah Siswa & 27 & 27 \\
\% Aktivitas & 69,68 & 72,11 \\
Skor Tertinggi & 29 & 27 \\
Skor Terendah & 19 & 19 \\
Standar Deviasi & 3,28 & 2,13 \\
Kategori & Baik & Baik \\
\hline
\end{tabular}

Persentase aktivitas siswa tiap indikator pembelajaran materi Elastisitas bahan setelah digunakan dengan metode eksperimen dapat dilihat pada Gambar 1.

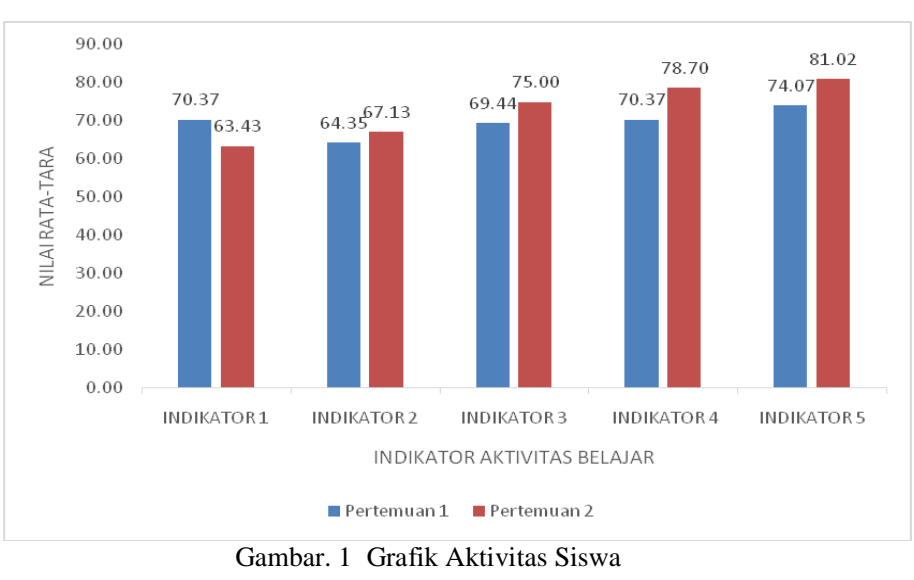

Berdasarkan grafik aktivitas siswa pada Gambar 1, dapat dilihat bahwa dari aktivitas siswa meningkat dari pertemuan 1 ke pertemuan 2 yaitu pada indikator 2) Kegiatan-kegiatan lisan. 3) Kegiatan-kegiatan mendengarkan. 4) Kegiatankegiatan menulis. 5) Kegiatan motorik. Hal ini menunjukkan siswa mulai tampak peningkatan 


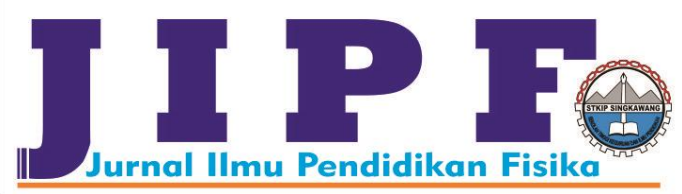

aktivitasnya melalui pembelajaran dengan metode eksperimen. Pada indikator 1) yaitu kegiatankegiatan visual, aktivitas siswa menurun dari pertemuan 1 ke pertemuan 2. Namun secara keseluruhan aktivitas siswa dapat dikatakan meningkat sesuai dengan persentase aktivitas siswa pada Tabel 5.

Pembelajaran dengan metode eksperimen melatih dan mengajar siswa untuk belajar secara aktif dengan mengikuti tahap-tahap pembelajarannya. Belajar sambil melakukan aktivitas lebih banyak mendatangkan hasil bagi anak didik, sebab kesan yang didapatkan oleh anak didik lebih tahan lama tersimpan didalam benak anak didik [2]. Penerapan metode eksperimen ini diharapkan dapat membantu siswa untuk dapat memahami konsep elastisitas bahan.

\section{KESIMPULAN DAN SARAN}

Berdasarkan hasil analisis data terhadap penerapan metode eksperimen berpengaruh terhadap hasil belajar dan aktivitas siswa pada materi elastisitas bahan di kelas MAN Model Singkawang dapat disimpulkan hasil belajar siswa setelah diberikan pembelajaran dengan metode eksperimen mencapai KKM dengan rata-rata 78 .

Aktivitas siswa pada pembelajaran dengan metode eksperimen pada pertemuan pertama dan keduadengan persentase $70,89 \%$ dengan kategori baik.

Berdasarkan hasil penelitian ini adapun saran yang harus diperhatikan dalam penelitian ini yaitu peran guru dalam membimbing pada saat siswa melakukan percobaan untuk mendapatkan hasil belajar dan penguasaan konsep pada materi pembelajaran diharapkan lebih optimal. Selain itu untuk penelitian selanjutnya metode eksperimen dapat digunakan untuk melihat keterampilan proses sains siswa dalam pembelajaran.

\section{DAFTAR PUSTAKA}

[1] BSNP (2006). Silabus Pembelajaran Fisika. Jakarta: Diknas

[2] Supirman. (2013). Penggunaan Metode Eksperimen untuk Meningkatkan Aktivitas Belajar Siswa dalam Pembelajaran Ilmu Pengetahuan Alam. Pontianak: JurusanPendidikan Dasar FKIP UNTAN Pontianak

[3] Sudjana, N. 2011. Penilaian Hasil Proses Belajar Mengajar. Bandung: Remaja Rosdakarya.Hamalik, O. (2005). Proses Belajar Mengajar. Jakarta: Bumi Aksara.

[4] Puspita, A. dan Suryanti. (2015). Pengaruh Penerapan Metode Eksperimen Terhadap Hasil Belajar dan Keterampilan Berpikir Kreatif Di Sekolah Dasar. JPGSD, Volume 03 Nomor 02 Tahun 2015.

[5] Handhika, J. (2010). Pembelajaran Fisika Melalui Inkuiri Terbimbing Dengan Metode Eksperimen dan Demonstrasi Ditinjau Dari Aktivitas Dan Perhatian Mahasiswa. JP2F, Volume 1 Nomor 1 April 2010. 